\title{
УДК 621.821
}

DOI: 10.31651/2076-5835-2018-1-2020-1-4-10

\author{
Артеменко Богдан Олександрович \\ аспірант \\ ЧНУ ім. Б. Хмельницького, \\ кафедра спортивних ігор \\ bogdan198803@ukr.net \\ ORCID 0000-0001-9188-9375 \\ Пустовалов Віталій Олександрович \\ к.н.ф.в. і сп., доцент \\ ЧНУ ім. Б. Хмельницького, \\ кафедра спортивних ігор \\ v_pustovalov@ukr.net \\ ORCID 0000-0002-8625-6175 \\ Боєчко Федір Федорович \\ д.б.н., професор \\ ЧНУ ім. Б. Хмельницького, \\ кафедра біології та біохімії \\ ORCID 0000-002-4201-4027
}

\section{ВІКОВІ ОСОБЛИВОСТІ ФОРМУВАННЯ НЕЙРОДИНАМІЧНИХ ВЛАСТИВОСТЕЙ У ОСІБ 3 РІЗНИМ ХАРАКТЕРОМ ІГРОВОЇ ДІЯЛЬНОСТІ}

У статті представлено результати дослідження нейродинамічних властивостей у осіб з різним характером ігрової діяльності за допомогою комп'ютерної методики «Діагност-1». Встановлено, що нейродинамічні властивості покращується не залежно від характеру ігрової діяльності та досягають максимального розвитку у 18-19 років. Виявлено, більш високий рівень формування нейродинамічних властивостей у спортсменів ніж у не спортсменів.

Ключові слова: онтогенез; індивідуально-типологічні властивості; футбол; волейбол; фізичні навантаження.

\section{Постановка проблеми. Аналіз останніх публікацій}

Особливості та певні характеристики діяльності нервової системи людини є актуальним напрямом наукових досліджень [1]. Відомо, що постійні фізичні навантаження впливають на формування різних біологічних систем людини. Даним питанням довгий час займаються ряд науковців в результатах досліджень яких описано специфіку тренувальних впливів на організм людини. Зокрема з точки зору досліджень психофізіологічних та нейродинамічних властивостей $[2,3,4]$, показників морфо функціонального розвитку $[5,6]$, особливостей діяльності внутрішніх органів і систем під час тривалих фізичних навантажень [7, 8], відновлювальних засобів у спорті [9] та особливостей спеціальної фізичної підготовленості [10]. Проте, стан вивчення цих питань залишається розкритим не повністю і потребує доповнень та уточнень. Адже, не до кінця $є$ розкритими механізми впливу спеціальних фізичних навантажень у різних видах спорту на формування властивостей нервової системи людини. Останні, як відомо є генетично детерміновані і мало піддаються удосконаленню.

Діяльність атлета в різних видах спорту проявляється по різному і вимагає від організму певного виду адаптації. Адже, різні за характером види діяльності: силова, швидкісно-силова, робота на витривалість, спритність, гнучкість тощо по різному 
впливає на становлення психофізіологічних функцій, нейродинамічних властивостей, фізичної працездатності, діяльність внутрішніх органів тощо. Дане питання особливо цікаве для науковців з точки зору досліджень психофізіологічних та нейродинамічних властивостей. Так ряд авторів Г. В. Коробєйніков [3], Н. А. Дакал [2] у власних дослідженнях відмічають важливість когнітивних функцій в процесі засвоєння технікотактичних прийомів як у ігрових видах спорту так і в єдиноборствах. Вивчення особливостей когнітивних функцій, сенсомоторних властивостей атлета з врахуванням індивідуально-типологічних особливостей нервової системи створює можливості для розширення уявлень про реалізацію рухових навиків індивіда в умовах тривалого психоемоційного навантаження на основі цілеспрямованих пристосувальних психофізіологічних реакцій організму, що дозволяє підвищити ефективність організації та контролю навчально-тренувального та змагального процесів для спортсменів різного віку. Однією складовою психофізіологічних функцій індивіда $\epsilon$ генетичнодетерміновані складові, до яких відносять індивідуально-типологічні властивості ЦНС i їх вплив на прояв рухових реакцій людини $[11,12,13]$.

В умовах ігрового протиборства яскраво проявляються індивідуальнотипологічні та когнітивні властивості вищої нервової діяльності людини. Практично всі тактико-технічні прийоми в різних видах протиборств чи ігрових видах спорту потрібно виконувати за долі секунди щоб випередити суперника $[4,11]$. Враховуючи наведені вище дані наукових досліджень у спорті $є$ вкрай важливим і актуальним питанням виявлення перспективних нових шляхів досліджень особливостей нейродинамічних властивостей у спортсменів різної за характером м'язової діяльності.

Мета дослідження - виявити особливості формування індивідуальнотипологічних, нейродинамічних властивостей центральної нервової системи підлітків, юнаків та осіб зрілого віку з різним характером ігрової діяльності.

\section{Матеріали і методи дослідження}

Дослідження проводили у відповідності до Хельсенської декларації (прийнятої у 1964 р. у Хельсінкі, Фінляндія і переглянутої у жовтні 2000 р. у Единбурзі, Шотландія) і схвалена Етичним комітетом університету.

Визначення сенсомоторних та нейродинамічних, індивідуально-типологічних властивостей вищої нервової діяльності проводили у підлітків 14-15, юнаків 16-17 та 18-19 років та осіб зрілого віку (старше 20 років) за допомогою комп'ютерної системи та методики «Діагност-1» [14]. Для визначення латентного періоду простої зоровомоторної реакції (ПЗМР) досліджуваному пропонувалося якнайшвидше натискати правою (лівою) кнопкою при появі на екрані геометричної фігури. Результатом тесту було середнє значення реакції за 30 подразників з експозицією 700 мс. При тестуванні складної зорово-моторної реакції вибору одного подразника із трьох (PB1-3) була необхідність при появі на екрані «квадрат» якнайшвидше натискати праву кнопку на приладі. I не натискати при появі інших сигналів. Результатом було середнє значення РВ1-3 за 30 подразників з експозицією 900 мс. Для визначення часу складної зоровомоторної реакції вибору двох подразників із трьох (РВ2-3), досліджуваному необхідно було при появі на екрані фігури «квадрат» швидко натискати і відпускати праву кнопку правою рукою. При появі «кола» - натискати кнопку лівою рукою, а при появі «трикутника» не реагувати на подразник. Результатом був середній час реакції вибору РВ2-3 за 30 сигналів із експозицією 900 мс. Дослідження функціональної рухливості нервових процесів (ФРНП) визначався в режимі зворотного зв'язку. При появі на екрані фігури «квадрат», була необхідність натискати праву кнопку, «кола» ліву кнопку, «трикутника» - ігнорувати сигнал. В разі правильної відповіді експозиція наступного сигналу скорочувалася на 20 мс. Результатом було час необхідний для 
пред'явлення 120 сигналів [14]. Дослідження проводили на базі ВК «ІмпексагроСпорт» м. Черкаси, ВК «Фаворит» м. Лубни, СК «Сумихімпром» м. Суми, ВК «СумДу» м. Суми, ФК «Карпати» м. Львів, ФК «Черкаський Дніпро» м. Черкаси, дитячоюнацьких спортивних шкіл міст Суми, Полтава і Золотоноша. Результати дослідження було оброблено за допомогою комп'ютерного блоку програм Microsoft Excel. 3 метою аналізу отриманих результатів досліджень були використані такі статистичні показники: середнє арифметичне значення $(X)$, стандартне відхилення (SD). Значимість відмінностей показників вибірок визначалася за параметричним критерієм t-Стьюдента. Якщо розрахункове значення було більше граничного, то різниця між вибірками статистично значима $(\mathrm{p}<0,05)$.

\section{Результати дослідження та їх обговорення}

Аналіз результатів дослідження нейродинамічних властивостей у спортсменів та не спортсменів показав, що особи які систематично займалися ігровими видами спорту мали кращі результати у тестових завданнях, які відображали рівень розвитку нейродинамічних властивостей. На відміну від осіб, що не мали постійних фізичних навантажень у всіх досліджуваних вікових періодах результати у аналогічних тестових завданнях були гірші. Це може свідчити про нижчий рівень розвитку нейродинамічних властивостей. А починаючи із вікового періоду 18-19 років різниця у результатах тестових завдань для спортсменів та не спортсменів була статистично значимою (Табл.1).

Таблиця 1

Нейродинамічні властивості осіб різного віку та характеру ігрової діяльності

\begin{tabular}{|c|c|c|c|c|c|}
\hline $\begin{array}{l}\text { Вік, } \\
\text { Роки }\end{array}$ & $\begin{array}{c}\text { Досліджувані } \\
\text { показники }\end{array}$ & $\begin{array}{l}\text { ПЗМР } \\
(\mathrm{Mc})\end{array}$ & $\begin{array}{l}\text { PB1-3 } \\
\text { (Mc) }\end{array}$ & $\begin{array}{l}\text { PB2-3 } \\
(\mathrm{Mc})\end{array}$ & $\begin{array}{l}\text { ФРНП } \\
\text { (c) }\end{array}$ \\
\hline \multirow{3}{*}{$14-15$} & Волейболісти (25) & $241,5 \pm 3,5$ & $336,3 \pm 6,5$ & $417,6 \pm 4,1^{\mathrm{a}}$ & $67,1 \pm 0,4^{a}$ \\
\hline & Футболісти (29) & $248,4 \pm 8,4$ & $318,6 \pm 7,6$ & $411,8 \pm 8,6^{b}$ & $67,6 \pm 1,0^{b}$ \\
\hline & $\begin{array}{ll}\text { Не } & \text { спортсмени } \\
(28) & \end{array}$ & $250,0 \pm 3,2$ & $341,1 \pm 3,5$ & $448,3 \pm 6,2$ & $71,7 \pm 1,2$ \\
\hline \multirow{3}{*}{$16-17$} & Волейболісти (25) & $242,4 \pm 4,2$ & $322,4 \pm 8,6$ & $424,2 \pm 9,3^{\mathrm{a}}$ & $65,6 \pm 0,4^{a}$ \\
\hline & Футболісти (29) & $224,0 \pm 4,1$ & $301,2 \pm 7,9$ & $348,5 \pm 11,9^{b}$ & $59,4 \pm 1,2^{b}$ \\
\hline & $\begin{array}{ll}\mathrm{He} & \text { спортсмени } \\
(30) & \end{array}$ & $250,1 \pm 3,3$ & $346,4 \pm 3,2$ & $456,1 \pm 4,6$ & $66,5 \pm 1,2$ \\
\hline \multirow{3}{*}{$18-19$} & Волейболісти (21) & $232,1 \pm 3,2$ & $302,1 \pm 3,9$ & $372,1 \pm 4,5^{\mathrm{a}}$ & $63,7 \pm 0,4^{\mathrm{a}}$ \\
\hline & Футболісти (29) & $225,3 \pm 3,0$ & $323,4 \pm 5,6$ & $392,6 \pm 5,2^{b}$ & $61,5 \pm 0,5^{b}$ \\
\hline & $\begin{array}{ll}\mathrm{He} & \text { спортсмени } \\
(30) & \end{array}$ & $265,6 \pm 3,7$ & $348,4 \pm 4,6$ & $440,1 \pm 6,7$ & $65,4 \pm 1,6$ \\
\hline \multirow{3}{*}{$20-25$} & Волейболісти (19) & $227,9 \pm 2,6^{c}$ & $305,2 \pm 5,7^{\mathrm{c}}$ & $346,3 \pm 6,2^{c}$ & $62,1 \pm 0,5^{c}$ \\
\hline & Футболісти (29) & $226,4 \pm 5,1^{c}$ & $315,3 \pm 5,6^{c}$ & $402,7 \pm 8,1^{c}$ & $62,2 \pm 0,5^{c}$ \\
\hline & $\begin{array}{ll}\text { Не } & \text { спортсмени } \\
(28) & \end{array}$ & $256,6 \pm 6,1$ & $333,7 \pm 8,3$ & $410,1 \pm 9,0$ & $64,0 \pm 1,3$ \\
\hline
\end{tabular}

Примітка - вірогідність різниці на рівні $\mathbf{p}<0,05 ; \mathbf{a}-$ між волейболістами та не спортсменами; $\mathbf{b}$ - між футболістами та не спортсменами; с - між спортсменами різних вікових періодів.

Отримані результати дослідження нейродинамічних властивостей у осіб з різним характером ігрової діяльності дозволяють зробити декілька припущень. Зокрема, в процесі відбору та спортивного удосконалення в команди вищої спортивної майстерності, а це вік від 18 років і старше потрапляють гравці з високим або вище середнього рівня розвитку нейродинамічних властивостей. Так як досліджувані показники у цих вікових періодах для волейболістів та футболістів мають вірогідну 
відмінність у показниках від аналогічних результатів для спортсменів молодшого віку (17 років і молодші). Також, можемо припустити, що нижчий рівень розвитку нейродинамічних властивостей у людей, що не займаються систематично спортом і $\epsilon$ головним чинником який не дозволяє таким особам досягнути високих результатів у тому чи іншому виді спорту. Адже, раніше на матеріалах власних досліджень у різних ігрових видах спорту та єдиноборствах було встановлено модельні показники нейродинамічних функцій для спортсменів різного рівня спортивної кваліфікації $[1,4]$. Вирішення складних тестових завдань для діагностування рівня розвитку сенсомоторних реакцій (простої та реакції вибору одного і двох подразників із трьох), а також швидкості перероблення інформації (ФРНП) демонструють, що систематичне вирішення ігрових завдань гравцями сприяє розвитку функціональної організації діяльності ЦНС, яка удосконалюється із ростом спортивної майстерності. Та дозволяє успішно адаптуватися до швидких ігрових ситуацій в яких для прийняття рішення гравцеві відводиться 2-3 секунди, а подекуди і долі секунди. На відміну від осіб які не займаються систематично спортом їх нервова система не отримує таких постійних навантажень i відповідно не має аналогічних зрушень, a процес розвитку нейродинамічних властивостей проходить за загальними принципами онтогенезу людини. Підтверджено, що нейродинамічні функції суттєво впливають на властивість інтелекту розуміти вербальні реакції людини залежно від контексту ситуації, що їх спричинила [15]. Адже, в ігрових моментах спортсменам потрібно реагувати в першу чергу на рухові реакції суперника і на основі їх розуміння приймати рішення власних дій.

Наведені вище результати демонструють важливість врахування особливостей становлення та удосконалення нейродинамічних властивостей у процесі постійної ігрової діяльності, а також показники рівня розвитку даних властивостей ЦНС у різні вікові періоди можуть виступати як критерії при відборі до занять волейболом та футболом.

\section{Висновки}

1. Встановлено, що з віком формування сенсомоторних та нейродинамічних властивостей покращується не залежно від характеру ігрової діяльності та досягають максимальних значень з віком від 18 до 20 років.

2. Виявлено, що гравці різних ігрових видів спорту у більш старшому віці з 18 років і старше мали вірогідно вищі показники, ніж молодші гравці (17 років і молодші) у досліджуваних показниках.

3. Доведено, що процес формування та удосконалення сенсомоторних та нейродинамічних властивостей у спортсменів ігрових видів спорту протікає більш інтенсивно та характеризується випереджаючим характером в порівнянні із особами які не займаються спортом.

4. Більш динамічний, випереджаючий характер та вищий рівень розвитку нейродинамічних властивостей у спортсменів ніж у не спортсменів демонструє пластичність та можливість удосконалення досліджуваних властивостей ЦНС засобами фізичної культури і спорту.

Перспективи подальших досліджень. Перспектива подальших досліджень стосується вивчення особливостей психофізіологічних функцій та морфофункціональних характеристик у осіб з різним характером ігрової діяльності. 


\section{Список використаної літератури}

1. Лизогуб В. С., Пустовалов В. О., Супрунович В. О., Гречуха С. В. Сучасні підходи до реалізації відбору футболістів високої кваліфікації за показниками нейродинамічних властивостей вищих відділів центральної нервової системи. Слобожанський науково-спортивний вісник. 2017. № 2. С. 81-85. doi.org/10.15391/snsv.2017-2.008

2. Дакал Н. А. Психофізіологічні особливості елітних атлетів з урахуванням стилю ведення поєдинку. Теорія і методика фізичного виховання і спорту. 2015. № 1. С. 114-117.

3. Коробейніков Г. В., Міщук Д. М. Формування структури психофізіологічних особливостей волейболістів різних амплуа. Молода спортивна наука Украӥни. 2015. № 1. С. 103-108.

4. Коробейнікова Л. Г., Коробейніков Г. В., Міщенко В. С. Розподіл нейродинамічних показників у висококваліфікованих спортсменів за допомогою кластерного аналізу. Вісник Черкаського університету. 2016. № 2. C. 55-64.

5. $\quad$ Bayios I. A. Bergeles N. K., Apostolidis N. G., Noutsos K. S., Koskolou M. D. Anthropometric, body composition and somatotype differences of Greek elite female basketball, volleyball and handball players. The journal of sports medicine and physical fitness. 2006. № 46. P. 271-280.

6. Duncan M. J. Anthropometric and physiological characteristics of junior elite volleyball players. The journal of sports medicine and physical fitness. 2006. № 40. P. 649-651. doi: 10.1136/bjsm.2005.021998.

7. Босенко А., Долгієр Є. Особливості термінової адаптації центральної нервової системи волейболістів. Педагогічні науки: теорія, історія, інноваційні технології. 2018. № 3. С. 27-38. doi 10.24139/2312-5993/2018.03/027-038

8. Платонов В. Н. Допінг в олімпійському спорті: кризисне явище і шляхи його подолання. Педагогіка, психологія та медико-біологічні проблеми фізичного виховання і спорту. 2016. № 6. С. 53-59. doi:10.15561/18189172.2016.0608.

9. Виноградов В. Є. Стимуляція працездатності і відновлювальних реакцій в системі тренувальних впливів в підготовці кваліфікованих спортсменів : дис. ... д-ра. наук з фізичного виховання і спорту : 24.00.01 / Нац. ун-т фізичного виховання і спорту України. Київ, 2010. 349 с.

10. Бойченко Н. В., Ананченко К. В., Панов П. П. Вдосконалення координаційних здібностей юних дзюдоїстів. Проблемы и перспективы развития спортивных игр и единоборств в высших учебных заведениях. 2017. № 1. С. 12-16. http://nbuv.gov.ua/UJRN/edinob_2017_3_3

11. Мищук Д. Н. Критерии определения игрового амплуа на основе психофизиологических особенностей волейболистов : дис. ... канд. наук физ. воспит.: 24.00.01 / Нац. ун-т фізичного виховання і спорту України. Киев, 2014. 221 с.

12. Міщенко В. С., Коробейнікова Л. Г., Коробейніков Г. В. Психофізіологічний стан висококваліфікованих спортсменів 3 різним рівнем нейродинамічних функцій. Вісник Черкаського університету. 2017. № 2. C. 45-53. http://nbuv.gov.ua/UJRN/VchuB_2017_2_8

13. Коробейнікова Л. Г., Заповітряна О. Б., Мищенко В. С. Вікові особливості психофізіологічного стану у елітних спортсменів. Вісник Черкаського університету. 2015. № 19 С. 76-82.

14. Макаренко М. В., Лизогуб В. С. Онтогенез психофізіологічних функцій людини. Черкаси : Вертикаль, 2011.256 с.

15. Харченко С. В. Нейродинамічні властивості як передумова формування здібностей соціального інтелекту курсантів закладу вищої освіти зі специфічними умовами навчання. Теорія і практика сучасної психологіï. 2019. № 2. С. 115-118. http://www.tpsp-journal.kpu.zp.ua/index.php/archiv?id=1767

\section{References}

1. Lyzohub, V. S., Pustovalov, V. O., Suprunovich, V. O., \& Grechukha S. V. (2017). Modern approaches to the implementation of the selection of high-skilled football players according to the indicators of neurodynamic properties of the higher parts of the central nervous system. Slobozhanskyi Naukovo-Sportyvnyi Visnyk. (Slobozhansky Scientific and Sport Herald). 2. 81-85. (In Ukr.).

2. Dakal, N. A. (2015). Psychophysiological features of elite athletes, taking into account the style of the duel. Teoriia i metodika fizichnogo vikhovannia i sportu (Theory and methods of physical education and sports). 1. 114-117. http://nbuv.gov.ua/UJRN/TMFVS_2015 1 222 (In Ukr.).

3. Korobeinikov, G. V., \& Mishchuk, D. N. (2015). Formation of the structure of psychophysiological features of volleyball players of different roles. Moloda Sportyvna Nauka Ukrainy. (Young sports science of Ukraine.) 1. 103-108. http://repository.ldufk.edu.ua:8080/bitstream_18.pdf (In Ukr.).

4. Korobeinikova, L. G., Korobeinikov, G. V., Mishchenko, V. S. (2016). Distribution of neurodynamic indicators in highly qualified athletes using cluster analysis. Visnyk Cherkaskoho universytetu. (Bulletin of Cherkasy University). 2. 55-64. (In Ukr.).

5. Bayios, I. A., \& Bergeles, N. K., \& Apostolidis, N. G., \& Noutsos, K. S., \& Koskolou, M. D. (2006). Anthropometric, body composition and somatotype differences of Greek elite female basketball, volleyball and 
handball players. Zhurnal sportyvnoi medytsyny ta fizychnoi kultury (The journal of sports medicine and physical fitness). 46. 271-280. https://pubmed.ncbi.nlm.nih.gov/16823358/ (In Uk.).

6. Duncan, M. J. (2006). Anthropometric and physiological characteristics of junior elite volleyball players. Zhurnal sportyvnoi medytsyny ta fizychnoi kultury (The journal of sports medicine and physical fitness). 40. 649-651. doi: 10.1136/bjsm.2005.021998. (In Uk.).

7. Bosenko, A, \& Dolgier, E. (2018). Features of urgent adaptation of the central nervous system of volleyball players. Pedahohichni Nauky Teoriia Istoriia Innovatsiini Tekhnolohii. (Pedagogical sciences: theory, history, innovative technologies). 3. 27-38. doi 10.24139/2312-5993/2018.03/027-038 (In Ukr.).

8. Platonov, V. N. (2016). Doping in Olympic sports: crisis phenomena and ways to overcome them. Pedagogika, psikhologiia ta mediko-biologichni problemi fizichnogo vikhovannya i sportu. (Pedagogy, psychology and medical and biological problems of physical education and sports). 6. 53-59. doi:10.15561/18189172.2016.0608.

9. Vinogradov V. E. Stimulation of efficiency and restorative reactions in the system of training influences in the training of qualified athletes. Sc d dis. Kiev. 349. (In Ukr).

10. Boychenko, N. V., \& Ananchenko, K. V., \& Panov, P. P. (2019). Development and improvement of coordination skills in judo. Problemy i perspektyvy rozvytku sportyvnykh ihor i yedynoborstv u vyshchykh zakladakh navchannia. (Problems and prospects for the development of sports games and martial arts in higher education). 1. 12-16. http://nbuv.gov.ua/UJRN/edinob $2017 \quad 3 \quad 3$ (in Ukr).

11. Mishchuk, D. N. (2014). Criteria for determining the role of play based on the psychophysiological features of volleyball players. Sc cand. dis. Kiev. 221. (In Ukr).

12. Mishchenko, V. S., \& Korobeinikova, L. G., \& Korobeinikov, G. V. (2017). Psychophysiological state of highly skilled athletes with different level of neurodynamic functions. Visnyk Cherkaskoho universytetu. (Bulletin of Cherkasy University). 2. 45-53. http://nbuv.gov.ua/UJRN/VchuB 201728 (In Ukr.).

13. Korobeinikova, L. G. \& Zapovitryana, O. B., \& Mishchenko, V. S. (2016). Age features of psychophysiological condition in elite athletes. Visnyk Cherkaskoho universytetu. (Bulletin of Cherkasy University). 19. 76-82. http://nbuv.gov.ua/UJRN/VchuB 20151912 (In Ukr).

14. Makarenko, M. V., \& Lyzohub, V. S. (2011). Ontogenesis of psychophysiological functions of a person. Cherkassy. Vertical. (In Ukr.).

15. Kharchenko, S. V. (2019). Neurodynamic properties as a prerequisite for forming the abilities of social intelligence of cadets of higher education institutions with specific learning conditions. Teoriya i praktika suchasnoyi psikhologiyi (Theory and practice of modern psychology). 2. 115-118. http://www.tpspjournal.kpu.zp.ua/index.php/archiv?id=1767 (In Ukr).

16.

Artemenko B.O., Pustovalov V.O., Boechko F.F. The age peculiarities to formation of neurodynamic properties in persons with different nature of gaming activities

Introduction. It is known that neurodynamic properties are genetically determined and may be a criterion in the selection process for various sports. as well as neurodynamic functions significantly affect the process of becoming a sportsmanship.

Purpose. To reveal the peculiarities to formation of the individual-typological, neurodynamic properties of the central nervous system of teenagers, young people, and mature people with different nature of play activities.

Methods. Computer testing of neurodynamic functions in persons with different nature of play activities.

Results. It was found that sportsmen's neurodynamic functions were significantly different from those who do not have constant physical activity. However, there were no significant differences in the studied indicators between different age groups of football players and volleyball players.

Originality. The features of the distribution of neurodynamic functions for athletes and nonathletes according to their age are revealed.

Conclusion. According to the results of the study, it is established that individuals who regularly engage in physical exercise, prevail in the level of development of the studied neurodynamic properties of people who do not do sports. It was found that both footballers and volleyball players aged 18 and older had higher scores compared to younger players, but did not have significant differences in the studied figures. The study of neurodynamic properties in people with different levels of physical activity demonstrates the levels of indicators of neurodynamic functions for athletes of different ages, which can be used in the selection process for football and volleyball. It is proved that the process of formation and improvement of sensorimotor and neurodynamic properties in athletes of 
game sports is more intense and is characterized by an advanced nature in comparison with nonathletes.

Keywords:, ontogeny; individual-typological propertie; football; volleyball; physical activity.

Одержано редакцією

Прийнято до публікації
28.01 .2020

11.06 .2020 